\title{
INDIKATOR TERCIPTANYA MASYARAKAT MADANI PERSPEKTIF AL-QUR'AN
}

\author{
Ahmad Mustaniruddin \\ UIN Sulthan Thaha Saifuddin Jambi \\ Email: ahmad_mustanirruddin@uinjambi.ac.id
}

\section{Hery Afriyadi}

UIN Sulthan Thaha Saifuddin Jambi

Email: heridoang75@gmail.com

\section{Jamilah}

UIN Sulthan Thaha Saifuddin Jambi

Email: jamilah@uinjambi.ac.id

\begin{abstract}
Creating an ideal life for society is not solely the responsibility of society itself, but it requires collaboration between society and the state in creating a peaceful, prosperous, open, advanced and modern society or better known as civil society. The role of the Koran as a guideline for human life should also talk about this. Therefore, it is necessary to reveal the indicators of civil society in the Koran so that the idealized term of civil society can be realized. By using the content analysis method, this article describes and reveals what indicators must be met to realize civil society in Indonesia as contained in the al-Qur'an. This article finds that in order to realize what is called civil society in Indonesia, the state needs to carry out its obligations and fulfill the rights of its people as well as uphold the principles of faith, humanity, unity, deliberation and justice, and the society becomes a civilized society, upholds it. Human values as well as divine values highlight the material dimension as well as the spiritual dimension built on the pillars of religion and advance in the mastery of science and technology.
\end{abstract}

Keywords: Indocator, Society, Madani, al-Qur'an

\begin{abstract}
Abstrak
Menciptakan kehidupan yang ideal bagi masyarakat bukan semata tanggung jawab masyarakat itu sendiri, namun diperlukan kolaborasi antara masyarakat dan negara dalam menciptakan masyarakat yang damai, sejahtera, terbuka, maju, dan modern atau yang lebih dikenal
\end{abstract}


sebagai masyarakat madani. Peranan al-Qur'an sebagai pedoman hidup manusia semestinya juga membicarakan tentang hal tersebut. Oleh karenanya, perlu mengungkap indikator masyarakat madani dalam alQur'an agar term masyarakat madani yang diidam-idamkan dapat terwujud. Dengan menggunakan metode analisis isi, artikel ini menjelaskan dan mengungkap apa saja indikator yang wajib dipenuhi untuk mewujudkan masyarakat madani di Indonesia yang terdapat dalam al-Qur'an. Artikel ini menemukan bahwa untuk mewujudkan apa yang disebut dengan masyarakat madani di Indonesia, negara perlu menjalankan kewajibannya dan menunaikan hak-hak rakyatnya serta menjunjung tinggi prinsip-prinsip keimanan, kemanusiaan, persatuan, permusyawaratan dan keadilan, dan masyarakatnya menjadi masyarakat yang beradab, menjunjung tinggi nilai-nilai kemanusiaan sekaligus nilainilai ketuhanan, menonjolkan dimensi material sekaligus dimensi spiritual yang dibangun di atas pilar agama serta maju dalam penguasaan ilmu pengetahuan, dan teknologi.

Kata Kunci: Indikator, Masyarakat, Madani, al-Qur’an

\section{Pendahuluan}

Perkembangan era globalisasi yang tengah berlangsung saat ini membawa akibat khusus untuk kehidupan warga Indonesia. Kemajuan teknologi sudah mengikis habis margin yang mengekang kehidupan manusia. Sebab itu, muncullah masyarakat terbuka atau open society di mana terjadi gelombang bebas informasi baik dalam perdagangan, maupun berbagai model kegiatan dalam kehidupan global lainnya yang mampu mempersatukan manusia dari beragam penjuru dunia. Masyarakat mesti sadar betapa penting mengupayakan hak asasinya dan mesti bertanggung jawab atas kehidupan dalam membentuk kondisi masyarakatnya sendiri.

Oleh sebab itu, tanggung jawab bersama telah menjadi sebuah hal yang lazim dalam memajukan dan membangun kehidupan masyarakat Indonesia kedepannya. Tanggung jawab ini tidak dibebankan hanya kepada masyarakat sendiri atau hanya kepada negara saja melainkan menjadi tanggung jawab bersama, yaitu pemerintah serta semua warga negara. Bentuk masyarakat yang diidamkan pastinya merupakan masyarakat yang harmoni, 
sentosa, terbuka, berkembang, serta modern atau yang disebut sebagai "civil society" atau "masyarakat madani", bukan sebagai masyarakat yang merendahkan dan mengabaikan hak asasi manusia itu sendiri.

Terciptanya masyarakat madani merupakan tanggung jawab bersama antara pemerintah dan masyarakat. Keduanya harus bersinergi dan bekerja sama sebagai mitra dalam membangun masyarakat yang ideal. Namun, kerja sama antara pemerintah dan masyarakat dapat terlaksana apabila ada nilai kepercayaan di antara keduanya. Djamaludin Ancok mengatakan bahwa membangun kepercayaan masyarakat terhadap pemerintah adalah prasyarat utama terciptanya masyarakat madani yang penuh damai dan demokratis. ${ }^{1}$ Agus Dwiyanto juga menyatakan bahwa peran pemerintah sangat penting dalam terciptanya masyarakat madani. Pemerintah harus bersikap all-inclusive dalam pengertian bahwa pemerintah mampu mengakomodasi keragaman yang ada dalam masyarakat serta memfasilitasi mereka semua tanpa membedabedakan antara satu dan lainnya. ${ }^{2}$

Masyarakat madani yang diciptakan oleh Nabi Muhammad saw. ketika berada di Madinah sebagai pemimpin negara memiliki ciri-ciri di atas. Hal ini tercermin dari butir-butir Piagam Madinah yang ia tetapkan sebagai konstitusi Madinah. Oleh karena itu,-menurut Syahdara Anisa Makruf-pentingnya kepemimpinan profetik sebagaimana yang dicontohkan oleh Nabi saw. dalam mewujudkan masyarakat madani. ${ }^{3}$ Bagi umat Islam, nilai-nilai

1 Djamaludin Ancok, "MEMBANGUN KEPERCAYAAN MENUJU INDONESIA MADANI, DEMOKRATIS DAN DAMAI (Sebuah Tinjauan Psikologi Sosial)," Buletin Psikologi 10, no. 2 (29 September 2015): 56, https://doi.org/10.22146/bpsi.7451.

2 Agus Dwiyanto, "Membangun Masyarakat Madani: Tinjauan BirokratikPolitik," JKAP (Jurnal Kebijakan Dan Administrasi Publik) 3, no. 1 (21 Desember 2015): 93, https://doi.org/10.22146/jkap.8484.

3 Syahdara Anisa Makruf, "Urgensi Kepemimpinan Profetik dalam Mewujudkan Masyarakat Madani," Ta'dib: Jurnal Pendidikan Islam 6, no. 2 (1 November 2017): 251, https://doi.org/10.29313/tjpi.v6i2.3169. 
kepemimpinan profetik tersebut dapat ditelusuri di dalam alQur'an. Karena al-Qur'an—secara normatif-diyakini sebagai pedoman kehidupan umat manusia termasuk persoalan mewujudkan terciptanya masyarakat madani.

Al-Qur'an sebagai asas kehidupan manusia manusia khususnya umat muslim mesti senantiasa berpartisipasi untuk membangun terwujudnya masyarakat madani di negeri mayoritas muslim (Indonesia). Belakangan ini hampir seluruh masyarakat penjuru dunia mendambakan hidup dengan demokrasi partisipatoris, yaitu kehidupan yang meniscayakan rakyatnya agar mempunyai kemampuan untuk turut serta dalam memajukan masyarakatnya sendiri. Pertumbuhan demokratisasi ini pastinya membutuhkan pedoman atau asas yang cocok dan sesuai. Maka penyusunan bentuk masyarakat madani dengan aturan nilai yang hendak diwujudkan terikat dengan konfigurasi nilai yang ada dalam al- Qur'an sebagai asas/pedoman. Kiranya penting mengungkap indikator terciptanya masyarakat madani dalam kitab suci al-Qur'an sehingga peran al-Qur'an selaku pedoman hidup dapat terealisasi dalam kolaborasi masyarakat dan negara pada perwujudan masyarakat madani di Indonesia.

\section{Pembahasan}

Term "Masyarakat Madani” memang tidak ditemukan dalam al-Qur'an. Namun, konsep masyarakat madani yang terdiri dari dua unsur yaitu masyarakat ideal dan negara utama dapat ditelusuri melalui dua kata kunci yaitu kata ummah dan madinah. Kedua term ini dapat ditemukan dalam al-Qur'an sebagaimana berikut.

\section{Masyarakat Ideal}

Gambaran masyarakat ideal dalam al-Qur'an bisa ditemukan dalam beberapa ayat yang memuat frasa seperti "masyarakat terbaik" (khayru ummah), "masyarakat yang sepadan" (ummatan wasathhan), "masyarakat yang seimbang/moderat" (ummah 
muqtashidah) serta "masyarakat tunggal" (ummah wabidah). Berikut ini dilansir ayat al-Qur'an yang memakai istilah tersebut:

a. Khayra ummah dalam QS. Ali Imran [3]: 110, yaitu:

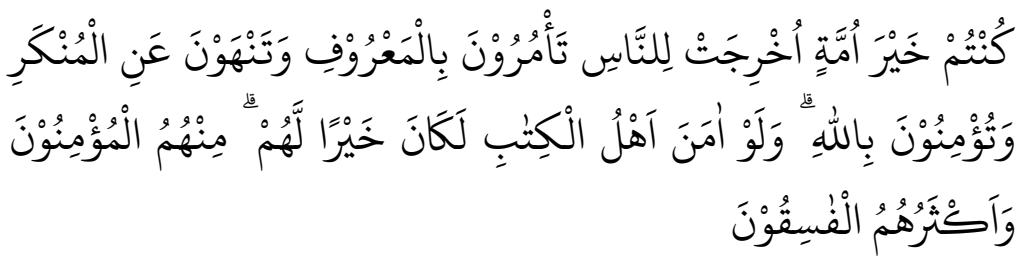

Kamu adalab umat yang terbaik yang dilabirkan untuk manusia, menyurub kepada yang ma'ruf, dan mencegah dari yang munkar, dan beriman kepada Allah. Sekiranya Abli Kitab beriman, tentulah itu lebih baik bagi mereka, di antara mereka ada yang beriman, dan kebanyakan mereka adalah orang-orang yang fasik..

Term khayra ummah dalam QS. Ali Imran [3]: 110 di atas merupakan bentuk masyarakat terbaik dan sempurna, ditugaskan sebagai pengembang sejumlah fungsi profetik, terutama selalu mengajak kepada kebaikan dan mencegah segala kemungkaran, serta menghindari perselisihan setelah mendapat keterangan yang kongkrit. Al-Qur'an memberikan beberapa petunjuk tentang mekanisme perdamaian guna menyelesaikan masalah internal, yaitu musyawarah, rekonsiliasi, dan berdakwah dengan metode al-hikmah wa al-mujadalah billati hiya absan (menyeru dan mengajak dengan bijaksana serta melakukan perundingan dengan metode yang lebih utama). ${ }^{5}$

Berdasarkan ayat tersebut Allah telah menyatakan dalam alQur'an bahwa umat Islam merupakan umat terbaik dari seluruh golongan manusia ciptaan-Nya. Aspek kebaikan umat Islam di antaranya diukur dengan keunggulan kualitas SDM-nya dibanding umat agama lain. Keutamaan umat Islam sebagaimana maksud dalam al-Qur'an itu sifatnya normatif dan potensial. Kendati

4 Departemen Agama RI, Al-Qur'an dan Terjemabnya (Bandung: Diponegoro, 2009), 64.

${ }^{5}$ QS. al-Nahl: 125

168 | TAJDID vol. 19, No. 2, Juli - Desember 2020 
demikian, predikat tersebut tidak serta merta disematkan kepada setiap muslim. Terdapat sejumlah kriteria yang harus terpenuhi pada kaum muslimin untuk menyebut mereka sebagai khayru ummah. ${ }^{6}$

Umat terbaik di dunia ialah umat yang memiliki dua ragam sifat, yaitu mengajak kepada kebaikan lalu mencegah segala kemungkaran, dan juga selalu beriman kepada Allah. Seluruh sifat tersebut telah tertanam pada kaum muslimin era Nabi dan telah mendarah daging pada diri mereka, sebab itu mereka menjadi umat yang kuat dan berjaya. Dalam kurun waktu yang relatif singkat mereka mampu menundukkan seluruh tanah Arab dan patuh dalam naungan panji Islam, hidup damai dan harmonis di bawah panji keadilan, padahal sebelumnya mereka selalu berpecah belah dan berada dalam kekacauan serta saling berperang satu sama lain. Hal ini disebabkan keteguhan iman serta kepatuhan mereka dalam beragama dan berkat kesabaran dan kesungguhan mereka dalam menjalankan amar ma'ruf naby munkar. Kalau ayat ini dihubungkan dengan QS. Ali Imran [3]: 102-104, dapat ditarik pemahaman bahwa umat pilihan itu adalah umat yang mempunyai kriteria: (1) beriman; (2) bertakwa; (3) memegang teguh agama Allah; (4) memelihara tali persaudaraan; (5) berdakwah; (6) mengerjakan kebaikan; dan (7) mencegah kemungkaran. ${ }^{7}$

b. Ummatan wasathan dalam QS. Al-Baqarah [2]: 143, yaitu:

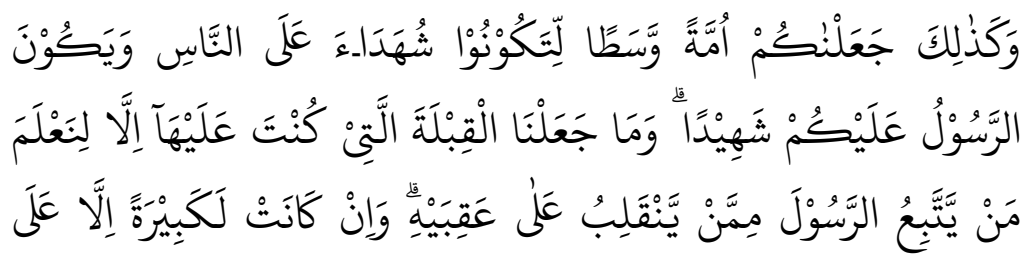

6 Mia Fitirah Elkarimah, "MASYARAKAT MADANI: PLURALITAS DALAM ISYARAT AL-QUR'AN,” EDUKASI: Jurnal Pendidikan Islam 4, no. 2 (1 November 2016): 392.

${ }^{7}$ Departemen Agama RI, Al-Qur'an dan Terjemahnya, 63. 


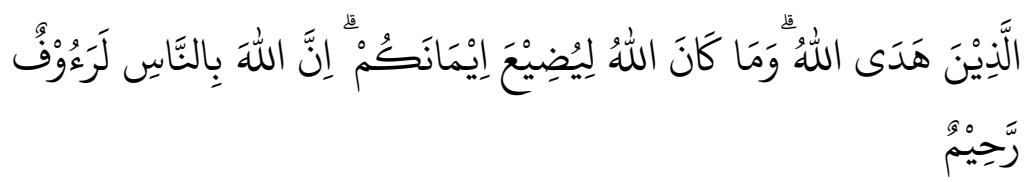

Dan demikian (pula) Kami telah menjadikan kamu (umat Islam), umat yang adil dan piliban agar kamu menjadi saksi atas (perbuatan) manusia dan agar Rasul (Mubammad) menjadi saksi atas (perbuatan) kamu. Dan Kami tidak menetapkan kiblat yang menjadi kiblatmu (sekarang) melainkan agar Kami mengetahui (supaya nyata) siapa yang mengikuti Rasul dan siapa yang membelot. Dan sungguh (pemindahan kiblat) itu terasa amat berat, kecuali bagi orang-orang yang telah diberi petunjuk oleh Allah; dan Allah tidak akan menyia-nyiakan imanmu. Sesunggubnya Allab Maba Pengasib lagi Maha Penyayang kepada manusia. $^{8}$

Istilah berikutnya yang juga memiliki arti masyarakat ideal ialah ummatan wasathan. Ayat di atas menjelaskan bahwa persyaratan sebagai umat yang ideal ialah memiliki sifat moderat. Berada pada posisi tengah membuat masyarakat itu tidak berpihak ke kiri dan ke kanan, sehingga mereka mampu berbuat adil. Term ummatan wasathan dalam ayat tersebut juga dapat dimaknai sebagai masyarakat yang proporsional. Masyarakat proporsional berada pada posisi tengah (wasthah), yaitu mengkombinasi sesuatu yang terbaik dari segala hal yang saling bertentangan. ${ }^{9}$

M. Quraish Shihab berpendapat bahwa pada awalnya kata wasath memiliki arti segala hal baik sesuai objeknya. Hal yang baik memposisikan diri antara dua yang ekstrim. Ia memberi contoh bahwa keberanian berada di antara sikap ceroboh dan takut. Sifat dermawan berada di antara boros dan kikir. Berawal dari hal tersebut, kata wasath kemudian berkembang artinya menjadi tengah. ${ }^{10}$

${ }^{8}$ Departemen Agama RI, 22.

${ }^{9}$ Kuntowijoyo, Identitas Politik Umat Islam (Bandung: Mizan, 1997), 4.

10 M. Quraish Shihab, Wawasan al-Qur'an: Tafsir Maudhu'i atas Pelbagai Persoalan Umat (Bandung: Mizan, 1996), 328. 
Masyarakat ideal yang berada pada posisi tengah menjadikan mereka berbeda dengan umat yang hanya terhanyut oleh materialisme namun juga tidak membuat mereka melambung tinggi sehingga tidak lagi berpijak di bumi. Berada pada posisi tengah membuat mereka mampu mengkombinasi aspek ruhani dengan aspek jasmani, material dengan spiritual dalam seluruh aktivitasnya. Dalam menghadapi pihak-pihak yang saling berselisih dituntut menjadi penengah/wasit dan mesti bersikap moderat agar mampu berlaku adil. Dari hal ini, lahirlah arti ketiga kata wasath, yaitu adil.

Ummatan wasatha adalah umat yang moderat, yang berada pada posisi tengah, agar tampak oleh seluruh pihak, dan dari segala penjuru. Mereka dijadikan demikian-berdasarkan lanjutan ayat di atas-supaya mereka menjadi saksi dan menjadi teladan bagi yang lainnya, dan pada waktu yang sama mereka meneladani Nabi Muhammad saw. dan sebagai asas pembenaran bagi seluruh aktivitasnya. Wasathiyah dalam arti moderasi atau berada pada posisi tengah mengundang interaksi umat Islam dalam dialog serta bersikap terbuka terhadap semua pihak baik agama, budaya, maupun peradaban, sebab mereka tidak bisa menjadi saksi ataupun bersikap adil jika mereka menutup dan membatasi diri dari lingkungan dan perkembangan era global. ${ }^{11}$

c. Ummah muqtashidah dalam QS. Al-Maidah [5]: 66, yaitu:

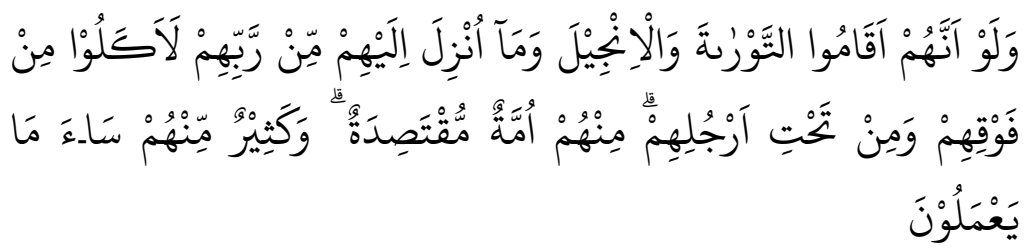

Dan sekiranya mereka sungguh-sungguh menjalankan (bukum) Taurat dan Injil dan (al-Qur'an) yang diturunkan kepada mereka dari Tuhannya, niscaya mereka akan mendapat makanan dari atas dan dari bawah kaki mereka. Di antara mereka ada golongan yang pertengahan.

${ }^{11}$ Shihab, 433-34.

TAJDID vol. 19, No. 2, Juli - Desember 2020 | 171 
Ahmad Mustaniruddin, Hery Afriyadi, dan Jamilah

\section{Dan alangkah buruknya apa yang dikerjakan oleh kebanyakan mereka. ${ }^{12}$}

Istilah lain pula yang juga mengandung makna masyarakat ideal adalah ummah muqtashidah yang diartikan sebagai masyarakat yang moderat, yakni entitas tertentu di kalangan ahli kitab, dan posisi ummah di situ adalah minoritas. Maksudnya adalah kelompok kecil dalam masyarakat yang tetap setia menebarkan kebaikan dan perbaikan serta meminimalisir kerusakan. Kelihatan bahwa makna ummah muqtashidah ini hampir identik dengan ummah wasath, karena keduanya mengandung makna moderat dan ketidakterjebakan pada titik ekstrim. Keduanya juga berfungsi memelihara konsistensi penerapan nilai-nilai utama di tengah berbagai komunitas sekitar yang telah menyimpang. Bedanya, cakupan ummah muqtashidah adalah sub komunitas seagama (Yahudi atau Nashrani), sedangkan ummah wasath adalah komunitas seagama itu sendiri, yakni Islam.

Kata umat itu sendiri mengandung empat prinsip utama, yaitu: a) solidaritas, kohesi di antara anggotanya, melintasi batas teritorial, dan heterogenitas (kelas, etnisitas); b) terikat dalam keyakinan yang sama (tauhid atau pemersatu); c) pemerintahan, yang berdasar pada tauhid bahwa Tuhan adalah kedaulatan mutlak, dan tunduk kepada aturan dan norma syari'ah; dan d) urusan bersama dilakukan dalam konsultasi saling menguntungkan dan diskusi (syura) di antara anggota umat, dan keputusan diambil melalui ijma' (konsensus di antara masyarakat dan/atau para ulama. $^{13}$

12 Departemen Agama RI, Al-Qur'an dan Terjemahnya, 119.

13 Fuad Fachruddin, Agama dan Pendidikan Demokrasi: Pengalaman Muhammadiyah dan Nabdlatul Ulama (Jakarta: Pustaka Alvabet dan Yayasan INSEP, 2006), 42. 
d. Ummah wabidah dalam QS. al-Baqarah [2]: 213, yaitu:

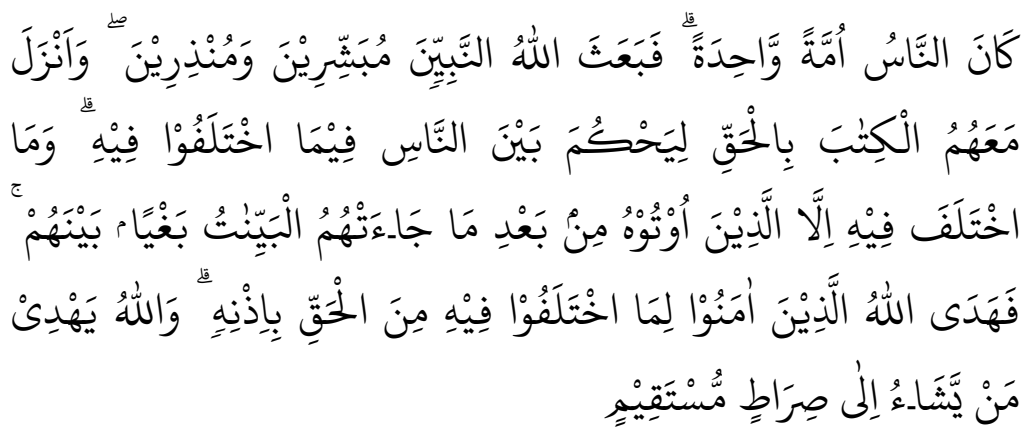

Manusia itu adalab umat yang satu. (setelah timbul perselisihan), Maka Allah mengutus Para Nabi, sebagai pemberi peringatan, dan Allah menurunkan bersama mereka kitab yang benar, untuk memberi keputusan di antara manusia tentang perkara yang mereka perselisibkan. Tidaklah berselisih tentang kitab itu melainkan orang yang telah didatangkan kepada mereka Kitab, yaitu setelah datang kepada mereka keterangan-keterangan yang nyata, karena dengki antara mereka sendiri. Maka Allah memberi petunjuk orang-orang yang beriman kepada kebenaran tentang hal yang mereka perselisibkan itu dengan kehendak-Nya. Dan Allah selalu memberi petunjuk orang yang dikehendaki-Nya kepada jalan yang lurus. ${ }^{14}$

Kemudian istilah berikutnya yang mengandung makna masyarakat ideal adalah ummatan wabidah. Term ummatan wabidah terdiri dari dua suku kata, yaitu ummah dan wahidah. Kata ummah, sebagaimana telah diterangkan sebelumnya, secara umum berarti sekelompok manusia atau masyarakat. Sedangkan, kata wabidah merupakan bentuk muannats dari kata wahid yang secara bahasa berarti satu. Istilah tersebut terulang dalam al-Qur'an sebanyak sembilan kali, yaitu terdapat dalam QS. Al-Baqarah [2]: 213; alMaidah [5]: 48; Yunus [10]: 19; Hud [11]: 118; al-Nahl [16]: 93; alAnbiya' [21]: 92; al-Zukhruf [43]: 33; al-Mu'minun [23]: 53 dan alSyura [42]: 8 .

${ }^{14}$ Departemen Agama RI, Al-Qur'an dan Terjemabnya, 33.

TAJDID vol. 19, No. 2, Juli - Desember 2020 | 173 
Dalam QS. Al-Baqarah [2]: 213 ini secara tegas dikatakan manusia dari dahulu hingga kini merupakan satu umat. Allah Swt. menciptakan mereka sebagai makhluk sosial yang saling berkaitan dan saling membutuhkan. Mereka sejak dahulu hingga kini baru dapat hidup jika tolong-menolong sebagai satu umat, yakni kelompok yang memiliki persamaan dan keterikatan. Karena kodrat mereka demikian, tentu saja mereka harus berbeda-beda dalam profesi dan kecenderungan. Ini karena kepentingan mereka yang banyak, sehingga dengan perbedaan tersebut masing-masing dapat memenuhi kebutuhannya. Dalam kenyataannya manusia tidak mengetahui sepenuhnya bagaimana cara memperoleh kemaslahatan mereka, juga tidak tahu bagaimana mengatur hubungan antar mereka, atau menyelesaikan perselisilian mereka. Di sisi lain, manusia memiliki sifat egoisme yang dapat muncul sewaktu-waktu, sehingga dapat menimbulkan perselisihan. Karena itu, Allah Swt. mengutus para rasul menjelaskan ketentuanketentuan-Nya dan menyampaikan petunjuk-Nya sambil menugaskan para rasul itu menjadi pemberi kabar gembira bagi yang mengikuti petunjuk. Hal ini diperkuat dengan kandungan QS. Yunus [10]: 19.

Manusia pada mulanya hidup rukun, bersatu dalam satu agama, sebagai satu keluarga. Tetapi setelah mereka berkembang biak dan setelah kepentingan mereka berlain-lain, timbullah berbagai kepercayaan yang menimbulkan perpecahan. Oleh karena itu, Allah mengutus rasul yang membawa wahyu dan untuk memberi petunjuk kepada mereka seperti yang tertera pada QS. AlBaqarah [2]: 213 tersebut. Ketetapan Allah itu ialah bahwa perselisihan manusia di dunia ini akan diputuskan di akhirat kelak. Kendati demikian, agaknya Allah memang tidak menghendaki adanya persatuan mutlak di antara manusia, sebab ada maksud tertentu di balik perbedaan itu, seperti dijelaskan dalam QS. AlMaidah [5]: 48; al-Nahl [16]: 93; Hud [11]: 118; dan al-Syura [42]: 8.

Adanya faktor pembeda di antara individu dan kelompok dalam masyarakat memberi peluang. Tetapi peluang itu harus 
diarahkan pada kompetisi ke arah kebajikan sebagaimana ditegaskan dalam QS. Al-Hujurat [49]: 13 yang melegitimasi terhadap adanya faktor pembeda itu sebagai sesuatu yang alami yang memang diciptakan oleh Tuhan. Tetapi ajaran agama menyatakan agar hal itu diperlakukan untuk saling mengenal (ta'aruff). Selain alami, keberagaman itu juga mengandung manfaat. Namun, manusia harus ingat bahwa mereka tergolong dalam umat manusia yang satu. Agama-salah satunya-berfungsi untuk mengingatkan persamaan di antara manusia itu sebagai landasan untuk persahabatan, persaudaraan, dan untuk saling tolongmenolong. Perbedaan itu tidak akan menjadi persoalan apabila kesemuanya itu mengacu pada nilai-nilai kebajikan.

Dengan demikian, kedatangan Islam dengan al-Qur'an sebagai kitab sucinya, selain mengembalikan bangsa yang terpecah kepada kepercayaan yang murni atau hanif-dalam arti sesuai dengan fitrah kejadian manusia yang paling dasar-juga mengandung misi mempersatukan individu-individu dalam satuan masyarakat yang lebih besar yang disebut dengan ummatan wabidah, yaitu suatu umat yang bersatu berdasarkan iman kepada Allah dan mengacu kepada nilai-nilai kebajikan.

Dari semua rumusan di atas, dapat dipahami bahwa walaupun manusia itu berbeda-beda, namun pada fitrahnya mereka adalah satu kesatuan terutama dalam hal keimanan dan kebajikan. Umat yang satu adalah isyarat yang diberikan al-Qur'an agar manusia tidak terpecah belah, sebab perpecahan yang terjadi hanya dilandasi oleh rasa dengki dan dorongan hawa nafsu manusia itu sendiri. Namun umat tersebut tidak terbatas kepada bangsa di mana mereka merupakan bagian. Arti umat mencakup pula seluruh umat manusia. Dalam hal ini, seluruh bangsa adalah bagian dari umat yang satu. Dengan demikian, maka kesatuan masyarakat didasarkan pada doktrin kesatuan umat manusia.

Dari empat term di atas, peneliti mengambil kesimpulan bahwa yang dimaksud masyarakat ideal itu adalah masyarakat yang 
beriman, bertakwa, berpegang teguh pada agama Allah, menjaga persaudaraan, berdakwah, menyuruh kepada kebaikan dan mencegah kemungkaran, berlaku adil, menjalankan hukum-hukum Allah dan menjaga persatuan.

\section{Negara Utama}

Di dalam karya fenomenal al-Farabi yang berjudul Ara' Abl al-Madinah al-Fadhilah, pembicaraan mengenai negara utama dimulai dengan keterangan asal-usul negara bahwa negara muncul karena kumpulan manusia, yang di dalamnya manusia membutuhkan manusia lainnya dalam memenuhi kebutuhan, dan ini adalah bibit pertama bagi lahirnya negara. Al-Farabi beranggapan bahwa negara lahir atas persetujuan bersama dari penduduk suatu masyarakat yang saling membantu memenuhi kebutuhan hidup. Setiap individu mempunyai kepandaian yang berbeda-beda, tapi berjanji akan menyumbangkan hasil kepandaiannya untuk memenuhi kebutuhan individu lainnya, agar tercapai cita-cita bersama, yaitu kebahagiaan. ${ }^{15}$

Al-Farabi mengklasifikasikan macam-macam negara berdasarkan ideologi yang dianut oleh negara itu sendiri. Ia tidak mengikuti cara-cara Yunani yang membagi negara menurut kepala negara seperti monarki, aristokrasi, dan demokrasi. Dan tidak pula ia sepakat dengan pembagian negara secara modern yang berdasarkan kepada kedaulatan rakyat, kedaulatan kekuasaan, dan kedaulatan hukum. Al-Farabi menempuh jalannya sendiri, yaitu pembagian berdasarkan ideologi, di mana al-Farabi menuliskan konsep negara utama beserta negara-negara yang berlawanan terhadap konsep negara utama. ${ }^{16}$

Negara utama menurut al-Farabi ibarat tubuh menusia yang satu bagian dengan bagian lainnya saling kerjasama sesuai dengan

15 Abu Nashr Muhammad al-Farabi, Ara'u Abl al-Madinah al-Fadbilah (Kairo: al-Hindawi, 2012), 69.

16 Ahmad Zainal Abidin, Negara Utama (Jakarta: Kinta, 1968), 57. 
tugasnya masing-masing. Jantung merupakan pusat dari segala organ tubuh tersebut. Organ yang satu bersifat melayani organ yang lain. Demikian pula negara yang terdiri dari warga negara dengan bakat dan kemampuan yang berbeda saling bekerjasama satu sama lain. Di antara mereka ada kepala negara dan sejumlah warga yang fungsinya berbeda satu sama lain sesuai dengan kapasitasnya. $^{17}$

Selanjutnya, al-Farabi menentukan persyaratan bagi kepala negara utama, yakni lengkap anggota badannya, baik daya pemahamannya, tinggi kecerdasannya, pandai mengemukakan pendapat dan mudah dipahami, cinta pendidikan dan cinta mengajar, tidak rakus dan loba terhadap makanan, minuman dan wanita, cinta kejujuran dan benci kebohongan, berjiwa besar dan berbudi luhur, tidak memandang penting kekayaan dan kesenangan duniawi yang lain, cinta keadilan dan menjauhi perbuatan keji, teguh pendirian terhadap hal-hal yang menurutnya harus dikerjakan serta teguh pendirian. ${ }^{18}$ Di samping syarat-syarat tersebut, al-Farabi menambahkan syarat lain yaitu pemimpin negara harus mampu naik pada akal fa'al (akal aktif) yang darinya wahyu dan ilham dapat diambil. Syarat-syarat ini sejalan dengan syarat yang disampaikan oleh al-Qur'an yaitu beriman dan bertakwa, sehat jasmani dan rohani, serta memiliki kemampuan, jujur, adil dan profesional, bertanggung jawab dan amanah, berani dan tegas, cinta kebenaran dan musyawarah. ${ }^{19}$ Persyaratan ini menunjukan bahwa seorang pemimpin bagi al-Farabi harus

17 Richard Walzer, Al-Farabi on The Perfect State; Abu Nasr Al-Farabi's Mabadi Ara'Abl Al Madinah Al-Fadilah (New York: Oxford University Press, 1985), 228.

18 Walzer, 246.

${ }^{19}$ Kementerian Agama RI, Tafsir al-Qur'an Tematik: al-Qur'an dan Kenegaraan (Jakarta: Lajnah Pentashih Mushaf al-Qur'an, 2011), 191. 
mampu mendidik dan menarik rakyat kepada jalan yang benar menuju kebahagiaan dunia dan akhirat. ${ }^{20}$

Madinah al-fadbilah (negara utama) menurut al-Farabi adalah negara yang didirikan oleh warga negara yang mempunyai tujuan yang tegas yaitu kebahagiaan. ${ }^{21}$ Selanjutnya, al-Farabi mengatakan bahwa kebahagiaan adalah kebaikan tertinggi dan diidam-idamkan. Tidak satu pun yang lebih tinggi daripadanya, yang mungkin dicapai oleh manusia. Kebahagiaaan tidak dapat diwujudkan kecuali dengan ilmu pengetahuan dan dengan usaha, yaitu kebahagiaan yang dikatakan al-Farabi sebagai kebahagiaan jasmani dan rohani, material dan spritual, untuk hidup dunia dan akhirat. ${ }^{22}$

Untuk mencapai kebahagiaan yang sempurna, tidaklah dapat dilakukan dengan berpikir dan bertindak sendiri-sendiri. Negara harus menghimpun segenap tenaga yang ada, dengan membuat rencana yang lengkap untuk melakukan pembangunan. Al-Farabi mengemukakan tiang-tiang utama bagi pembangunan yaitu: (1) kerja sama manusia secara kolektif; (2) kesucian pribadi masingmasing dalam pikiran dan perbuatan; dan (3) semangat kemasyarakatan berupa koperatif, harmoni, dan simpati. ${ }^{23}$

Dengan tiga tiang utama yang disebutkan di atas, maka sistem pembangunan tidak bersifat individualis. Al-Farabi tetap tidak mengingkari adanya hak perseorangan, tetapi menganjurkan supaya bekerja sama, gotong royong, dan saling simpati antara satu sama lain. Al-Farabi mengatakan bahwa di samping adanya hak milik bersama di mana masing-masing orang dan tiap-tiap kelas mempunyai hak yang sama, diizinkan pula mempunyai hak pribadi sebagai hasil dari kepandaian dan kerja keras. ${ }^{24}$

${ }^{20}$ Muhammad Azhar, Filsafat Politik; Perbandingan Antara Islam dan Barat (Jakarta: Raja Grafindo Persada, 1997), 81.

21 al-Farabi, Ara'u Abl al-Madinah al-Fadbilah, 89.

22 Abidin, Negara Utama, 72.

23 al-Farabi, Ara'u Abl al-Madinah al-Fadhilah, 64.

${ }^{24}$ al-Farabi, 38-44. 
Pada intinya, negara utama (al-madinab al-fadbilab), merupakan cermin negara yang memperjuangkan kemakmuran dan kesejahteraan warga negaranya. Segala kebijakan yang ditetapkan senantiasa diorientasikan demi kemaslahatan rakyat. Negara ini terwujud sebagai konsekuensi logis dari sistem yang menempatkan kepentingan rakyat di atas segalanya. Maka, negara dipenuhi dengan ketenteraman, kedamaian, dan kesejahteraan.

Gagasan al-Farabi ini sesungguhnya sejalan dengan prinsip al-Qur'an. Al-Qur'an telah menjelaskan tentang gambaran negeri yang makmur, aman, tenteram dan sejahtera dalam firman-Nya QS. Saba' [34]: 15. Ayat ini menggambarkan tentang keadaan negeri yang sejahtera yaitu negeri Saba'. Al-Maraghi mengatakan bahwa penduduk negeri tersebut mendapat kenikmatan yang besar dan rezeki yang luas. Mereka diperintahkan untuk menikmatinya dan bersyukur kepada Allah dengan cara mengesakan-Nya dan beribadah kepada-Nya. ${ }^{25}$ Ini adalah sebuah gambaran dari negeri yang sejahtera yang dalam QS. Al-Nahl [16]: 112 disebut dengan baldatun thayyibatun wa rabbun ghafur.

Lebih lanjut al-Maraghi menjelaskan dalam tafsirnya bahwa melalui QS. Al-Nahl [16]: 112 ini Allah mengungkapkan sifat-sifat sebuah negeri di mana penduduknya merasa aman baik dari pada permusuhan, peperangan maupun lapar dan haus. Allah mendatangkan rezeki kepada negeri tersebut dari berbagai penjuru. ${ }^{26}$ Inilah salah satu bentuk dari negeri yang Allah limpahkan berkah kepadanya.

Selain itu, hal esensial yang ditekankan dalam negara utama adalah keadilan di mana pemimpin dan rakyat menjalankan kewajiban serta mendapatkan hak mereka. Oleh karenanya, keadilan termasuk salah satu prinsip-prinsip bernegara yang

25 Ahmad Mustafa al-Maraghi, Tafsir al-Maraghi, vol. XXII (Kairo: Mustafa al-Babi al-Halabi, 1946), 70.

26 Ahmad Mustafa al-Maraghi, Tafsir al-Maraghi, vol. XIV (Kairo: Mustafa al-Babi al-Halabi, 1946), 150. 
dikemukakan oleh al-Qur'an. Adapun prinsip-prinsip bernegara dalam al-Qur'an adalah sebagai berikut:

\section{1) Keimanan}

Kata keimanan atau iman, seperti kata ilmu dan amal, merupakan kata kunci yang banyak disebut dalam al-Qur'an. Keimanan mengandung pengertian yang multi dimensi. Keimanan juga disebut akidah, yaitu ajaran yang secara khusus berbicara tentang keimanan terhadap keesaan Allah Swt. yang menjadi pokok keimanan adalah menyangkut kepercayaan dan pengakuan bahwa tuhan itu ada dan esa, tiada tuhan selain Allah dan Muhammad adalah utusan Allah. Iman baru dipandang sempurna, apabila ada pengakuan dengan lisan, dibenarkan dengan hati, yakin tiada bercampur ragu, dan diwujudkan oleh amal perbuatan.

Persoalan keimanan terhadap keesaan Allah Swt. dijelaskan secara lugas dalam beberapa ayat al-Qur'an. Beberapa penjelasan tentang persoalan keimanan tersebut menunjukkan bahwa persoalan ini merupakan hal yang sangat urgen dipahami dan dihayati oleh manusia. Karena, iman menjadi pokok pangkal kehidupan batin. Menurutnya, jiwa yang tidak mendapat cahaya iman menjadi kosong, lemah, sakit, dan sangat membahayakan bagi diri dan masyarakat sekelilingnya. ${ }^{27}$ Ada banyak ayat al-Qur'an yang membicarakan tentang keesaan Allah di antaranya QS. Al-Nahl [16]: 22 dan 51; al-Baqarah [2]: 163; al-Isra' [17]: 22-23; al-Kahfi [18]: 110; al-Ikhlas [112]: 1-4; al-Mu'minun [23]: 91; dan al-Hasyr [59]: 22.

\section{2) Kemanusiaan}

Islam menjunjung tinggi nilai kemanusiaan. Al-Qur'an sebagai kitab suci dalam Islam sangat menghargai manusia, makhluk yang diberikan status lebih karena akal pikirannya. Jadi,

27 Hasan Bashri dan T.H. Thalhas, Aktualisasi Pesan al-Qur'an dalam Bernegara (Jakarta: Ihsan, 2008), 21. 
al-Qur'an memandang manusia mempunyai derajat, hak, dan kewajiban yang sama. Al-Qur'an tidak membedakan manusia berdasarkan suku atau keturunan. Asas ini digambarkan dengan indah dalam QS. Al-Hujurat [49]: 13.

Pelaksanaan ajaran prikemanusiaan ini dapat berupa kegiatan-kegiatan yang bermanfaat bagi masyarakat, seperti sikap berani, membela kebenaran, berlaku adil dengan sesamanya, mengembangkan rasa saling mencintai sesama manusia, dan mengembangkan sikap tolong menolong dalam kebaikan. Sikap prikemanusiaan tersebut penting untuk dibangun, karena pada dasarnya manusia adalah makhluk sosial yang tidak mungkin sanggup berdiri sendiri. Dengan demikian, melihat manusia yang mempunyai kemampuan terbatas, maka diperlukan sikap saling melakukan kerjasama dengan sesamanya. Dalam hubungan ini, Allah memberikan rambu-rambu melalui al-Qur'an. Di antara rambu-rambu tersebut adalah sikap adil. Terdapat sejumlah ayat alQur'an yang menjelaskan tentang sikap adil, di antaranya adalah QS. Al-Nisa' [4]: 135; al-Maidah [5]: 8; al-Hadid [57]: 25; al-Nahl [16]: 90; al-An'am [6]: 152; al-A'raf [7]: 29; dan al-Mumtahanah [60]: 8 .

Ayat-ayat di atas secara jelas menegaskan bahwa Allah Swt. memerintahkan manusia berlaku adil. Fakor kebencian tidak boleh menghalangi sesorang untuk berlaku adil dan sikap ini akan mendekati ketakwaan. ${ }^{28}$ Keadilan merupakan suatu proses yang berfungsi untuk mengobati keluhan-keluhan atau luka-luka, menegakkan hak, dan menghilangkan eksploitasi, penindasan, serta kezaliman yang terjadi. Dikatakan lebih lanjut, keempat dimensi inilah yang mewarnai konsep Islam tentang keadilan. ${ }^{29}$

Dari uraian diatas dapat ditarik benang merah bahwa sesuai konsep prikemanusiaan dalam al-Qur'an, manusia harus

${ }^{28}$ Muhammad Fakhruddin bin Dhiya' al-Din Umar al-Razy, Mafatih alGhaib, vol. II (Beirut: Dar al-Fikr, 1981), 180-81.

${ }^{29}$ Bashri dan Thalhas, Aktualisasi Pesan al-Qur'an dalam Bernegara, 21. 
diperlakukan sesuai dengan harkat dan martabatnya sebagai makhluk Allah. Setiap manusia mempunyai hak dan kewajiban dalam kesamaan derajat, tanpa perbedaan suku, keturunan, kedudukan sosial, dan warna kulit. Dalam hal Indonesia, diperlukan sebuah kesadaran bahwa setiap individu adalah bagian dari seluruh umat manusia, sehingga sikap hormat menghormati dan bekerjasama baik sesama anak bangsa maupun dengan bangsabangsa lain benar-benar nyata.

\section{3) Persatuan}

Persatuan dan kesatuan umat merupakan suatu hal penting dalam keselamatan suatu negara dan bangsa agar terhindar dari perpecahan yang disebabkan oleh kepentingan golongan atau pribadi. Ini dijelaskan oleh Allah Swt. dalam QS. Ali Imran [3]: 103. Ayat ini secara tegas menekankan perlunya persatuan dan melarang perpecahan, karena dengan persatuan akan terwujud suatu kekuatan yang tangguh. Negara tidak akan maju tanpa persatuan di antara warganya, walaupun mereka berbeda suku dan agama. Persatuan yang kokoh hanya akan tercapai bila berpegang teguh kepada agama Allah.

Namun, untuk menjalin persatuan dibutuhkan langkahlangkah yang cerdas dan strategis. Di antara langkah yang ditetapkan oleh al-Qur'an adalah membangun sikap baik dengan yang lainnya. Bukan membuat sikap yang memusuhi atau hal-hal yang menimbulkan permusuhan. Sebagaimana disebutkan dalam QS. Al-Hujurat [49]: 11, yang secara tegas melarang menghina, mencela, dan mengejek sesama manusia. Dalam ayat tersebut juga ada larangan memanggil seseorang dengan panggilan yang buruk. Karena perbuatan tersebut dapat merusak persatuan dan kesatuan umat. Konsepsi al-Qur'an tentang persatuan perlu terus ditanamkan pada diri setiap anak bangsa guna mengembangkan rasa cinta kebangsaan yang tinggi, demi terciptanya tatanan kehidupan tertib, damai, dan tenteram. 
4) Permusyawaratan.

Kata permusyawaratan berasal dari musyawarah. Istilah ini berasal dari kata syawara-yusyawiru, yang berarti berkonsultasi atau meminta pendapat. ${ }^{30}$ Kata ini disebut beberapa kali, dengan menggunakan kata wa syawir (bum), seperti yang terdapat dalam QS. Ali Imran [3]: 159, sedangkan yang menggunakan kata syura terdapat dalam QS. al-Syura [42]: 38. Kata syura bila diterjemahkan ke dalam bahasa Indonesia menjadi musyawarah atau mufakat. Musyawarah, menurut Muhammad Imarah, adalah satu di antara kewajiban dalam Islam. Tanpa musyawarah, manusia tidak dapat merasakan keamanan atas kehidupan dan dinamika hubungannya dengan kelompok masyarakat yang ditempatinya, juga atas terjaminnya keberlangsungan politik dan pengaturan urusan-urusan sosial dengan benar. Konsep musyawarah dalam Islam mencakup seluruh bidang kehidupan yang bertujuan untuk mewujudkan keamanan dalam seluruh bidang kehidupan. Konsep musyawarah dalam Islam tidak semata filsafat sistem tata Negara Islam. Ia merupakan filsafat hidup Islam, yang mencakup seluruh bidang pembangunan masyarakat Islam. ${ }^{31}$

Dalam konteks keluarga, Islam menjadikan musyawarah sebagai perangkat pokok untuk mencapai kesepakatan pendapat, yang di atasnya dibangun rasa kasih sayang, keteraturan, dan kedisiplinan. Sementara dalam urusan-urusan negara, Islam mewajibkan agar musyawarah menjadi pedoman untuk mengatur urusan manusia secara umum seperti disebutkan dalam QS. Ali Imran [3]: 159. Mengutip pendapat Ibnu Athiyah, Imarah berpendapat bahwa musyawarah adalah salah satu kaidah syariat dan hukum yang kuat. Pemimpin yang tidak mau bermusyawarah dengan ahli ilmu pengetahuan dan ahli agama, ia harus dilengserkan. Hal ini tidak diperselisihkan oleh kalangan ulama.

30 Majma' al-Lughah al-'Arabiyah, Mu'jam al-Wasith (Mesir: Maktabah alSyuruq al-Dauliyah, 2011), 518.

${ }^{31}$ Muhammad Imarah, Islam dan Keamanan Sosial (Jakarta: GIP, 2010), 12627. 
Menurutnya, musyawarah bukan semata-mata hukum biasa. Musyawarah adalah hukum yang kuat. Bahkan juga merupakan kaidah syariat dan dasar-dasar Islam. Islam menjadikan musyawarah salah satu sifat dari sifat-sifat kaum mukminin dan diharapkan unutk dipraktikkan dalam seluruh kehidupan manusia. ${ }^{32}$

\section{5) Keadilan}

Kata dasar keadilan adalah adil. Dalam al-Qur'an pengertian adil itu tidak hanya diwakili oleh kata adil saja; ada kata lain sebagai sinonimnya, yaitu qisth. Kata adil disebut 14 kali sebagai kata benda. ${ }^{33}$ Adil mempunyai arti dan makna yang sangat dalam, mencakup segenap bidang kehidupan dan pergaulan umat manusia sepanjang zaman dan disegenap penjuru. Ia mencakup keadilan dalam lapangan politik, ekonomi, sosial, dan budaya. ${ }^{34}$ Keadilan dalam Islam adalah suatu keharusan, karena hal tersebut merupakan satu di antara unsur vital kehidupan sosial dan kemanusiaan. Menurut Islam, keadilan bukan sekedar hak tetapi juga ketentuan wajib yang ditetapkan Allah Swt. bagi semua manusia tanpa pengecualian. ${ }^{35}$ Dalam QS. Al-Syura [42]: 15 Allah Swt. juga mewajibkannya bagi Rasulullah saw. dan memerintahkan agar selalu berlaku adil. Kemudian, dalam QS. Al-Nisa' [4]: 58 Allah juga mewajibkan para pemimpin dari kalangan ulama, pejabat, pemimpin masyarakat, hakim, agar berlaku adil terhadap rakyatnya atau terhadap siapapun tanpa pandang bulu.

Di antara contoh keadilan yang seringkali ditekankan dalam Islam adalah keadilan dalam hal pendistribusian kekayaan. Kewajiban zakat dan anjuran untuk bersedekah adalah salah satu bukti bahwa Islam menginginkan agar terwujud pemerataan bagi masyarakat yang lemah. Bahkan, Allah mencela orang-orang yang hanya menumpuk harta untuk kepentingan diri sendiri seperti

32 Imarah, 128-29.

33 M. Dawam Raharjo, Mewujudkan Satu Umat (Jakarta: Puzam, 2002), 367.

34 Bashri dan Thalhas, Aktualisasi Pesan al-Qur'an dalam Bernegara, 36.

35 Imarah, Islam dan Keamanan Sosial, 116. 
digambarkan dalam QS. Ali Imran [3]: 180. Perintah ini dipertegas oleh QS. Al-Taubah [9]: 103 yang mendorong untuk menyalurkan zakat kepada yang lemah.

Dengan demikian, al-Qur'an mendorong agar orang-orang lemah seperti orang miskin, fakir, anak terlantar, dan yatim piatu mendapat kesempatan harta. Ayat-ayat yang menjelaskan persoalan tersebut dapat dilihat dalam QS. Al-Baqarah [2]: 177; al-Nisa' [4]: 36; al-Nahl [16]: 90; dan al-Isra' [17]: 26. Islam, sebagai agama yang rahmatan lil 'alamin, menekankan umat manusia untuk berlaku adil dalam segala hal, termasuk adil dalam pendistribusian harta. Sehingga, orang-orang yang lemah juga dapat menikmati kehidupan ini dengan bahagia. Namun, dari semua prinsip-prinsip di atas, salah satu prinsip terpenting yang diisyaratkan oleh Allah dalam mewujudkan negeri yang sejahtera adalah beriman dan bertakwa kepada-Nya sebagaimana ditegaskan dalam QS. Al-A'raf [7]: 96. Oleh karenanya, dapat diketahui bahwa negara utama adalah negara yang pemerintahnya menjalankan kewajibannya dan menunaikan hak-hak rakyatnya serta berdiri pada prinsip-prinsip al-Qur'an seperti keimanan, kemanusiaan, persatuan, permusyawaratan dan keadilan.

\section{Penutup}

Dari penjelasan di atas dapat ditarik benang merah bahwa masyarakat madani adalah sebuah tatanan negara baik pemerintahan maupun warga negaranya yang menerapkan ajaranajaran al-Qur'an dalam kehidupan, dimana pemerintahnya menjalankan kewajibannya dan menunaikan hak-hak rakyatnya serta menjunjung tinggi prinsip-prinsip keimanan, kemanusiaan, persatuan, permusyawaratan dan keadilan, serta masyarakatnya menjadi masyarakat yang beradab, menjunjung tinggi nilai-nilai kemanusiaan sekaligus nilai-nilai ketuhanan, menonjolkan dimensi material sekaligus dimensi spiritual yang dibangun di atas pilar agama serta maju dalam penguasaan ilmu pengetahuan, dan 
Ahmad Mustaniruddin, Hery Afriyadi, dan Jamilah

teknologi. Apabila hal ini terealisasi, maka akan terwujudlah negara yang makmur dan sejahtera.

\section{Daftar Pustaka}

Abidin, Ahmad Zainal. Negara Utama. Jakarta: Kinta, 1968.

Ancok, Djamaludin. "MEMBANGUN KEPERCAYAAN MENUJU INDONESIA MADANI, DEMOKRATIS DAN DAMAI (Sebuah Tinjauan Psikologi Sosial)." Buletin Psikologi 10, no. 2 (29 September 2015). https://doi.org/10.22146/bpsi.7451.

'Arabiyah, Majma' al-Lughah al-. Mu'jam al-Wasith. Mesir: Maktabah al-Syuruq al-Dauliyah, 2011.

Azhar, Muhammad. Filsafat Politik; Perbandingan Antara Islam dan Barat. Jakarta: Raja Grafindo Persada, 1997.

Bashri, Hasan, dan T.H. Thalhas. Aktualisasi Pesan al-Qur'an dalam Bernegara. Jakarta: Ihsan, 2008.

Departemen Agama RI. Al-Qur'an dan Terjemabnya. Bandung: Diponegoro, 2009.

Dwiyanto, Agus. "Membangun Masyarakat Madani: Tinjauan Birokratik-Politik." JKAP Jurnal Kebijakan Dan Administrasi Publik) 3, no. 1 (21 Desember 2015): 83-93. https://doi.org/10.22146/jkap.8484.

Elkarimah, Mia Fitirah. "MASYARAKAT MADANI: PLURALITAS DALAM ISYARAT AL-QUR'AN." EDUKASI: Jurnal Pendidikan Islam 4, no. 2 (1 November 2016): 386-402.

Fachruddin, Fuad. Agama dan Pendidikan Demokrasi: Pengalaman Muhammadiyah dan Nahdlatul Ulama. Jakarta: Pustaka Alvabet dan Yayasan INSEP, 2006.

Farabi, Abu Nashr Muhammad al-. Ara'u Abl al-Madinah alFadhilah. Kairo: al-Hindawi, 2012.

Imarah, Muhammad. Islam dan Keamanan Sosial. Jakarta: GIP, 2010. 
Kementerian Agama RI. Tafsir al-Qur'an Tematik: al-Qur'an dan Kenegaraan. Jakarta: Lajnah Pentashih Mushaf al-Qur'an, 2011.

Kuntowijoyo. Identitas Politik Umat Islam. Bandung: Mizan, 1997.

Makruf, Syahdara Anisa. "Urgensi Kepemimpinan Profetik dalam Mewujudkan Masyarakat Madani." Ta'dib: Jurnal Pendidikan Islam 6, no. 2 (1 November 2017): 242-54. https://doi.org/10.29313/tjpi.v6i2.3169.

Maraghi, Ahmad Mustafa al-. Tafsir al-Maraghi. Vol. XXII. Kairo: Mustafa al-Babi al-Halabi, 1946.

- Tafsir al-Maraghi. Vol. XIV. Kairo: Mustafa al-Babi alHalabi, 1946.

Raharjo, M. Dawam. Mewijudkan Satu Umat. Jakarta: Puzam, 2002.

Razy, Muhammad Fakhruddin bin Dhiya' al-Din Umar al-. Mafatih al-Ghaib. Vol. II. Beirut: Dar al-Fikr, 1981.

Shihab, M. Quraish. Wawasan al-Qur'an: Tafsir Maudbu'i atas Pelbagai Persoalan Umat. Bandung: Mizan, 1996.

Walzer, Richard. Al-Farabi on The Perfect State; Abu Nasr Al-Farabi 's Mabadi Ara`Abl Al Madinah Al-Fadilah. New York: Oxford University Press, 1985. 